\title{
Pengembangan Governor Elektrik Berbasis Arduino sebagai Sistem Kontrol Turbin Air Screw
}

\author{
TARSISIUS KRISTYADI, REZA ADITYA, PRAMUDA NUGRAHA
}

\author{
Teknik Mesin Institut Teknologi Nasional Bandung, Indonesia \\ Email: kristyadi@itenas.ac.id
}

Received 3 Februari 2020 | Revised 6 April 2020 | Accepted 25 April 2020

\begin{abstract}
ABSTRAK
Suatu sistem PLTMH bertipe turbin screw telah direalisasikan di desa Ciherang, Banjaran Jawa Barat. Tetapi putaran turbin dan generator tidak dapat stabil, karena pembebanan pada generator selalu berubah-ubah. Oleh karena itu diperlukan sebuah sistem kontrol yang dapat menjaga putaran turbin pada kisaran $30 \mathrm{rpm}$ dan putaran generator pada kisaran $1500 \mathrm{rpm}$. Pada paper ini dikaji pengembangan sistem kontrol turbin air tipe screw, menggunakan governor elektrik. Perangkat governor elektrik ini berbasis Arduino, yaitu Arduino Mega 2560 dan Arduino Uno yang dilengkapi sensor putaran, dan motor listrik sebagai aktuator yang menggerakkan sebuah pintu air untuk mengatur bukaan bucket. Arduino Mega 2560 berfungsi sebagai microcontroller sedangkan Arduino Uno berfungsi sebagai pengatur pembukaan pintu. Hasil pengujian system menunjukkan bahwa system dengan Arduino ini dapat mengatur putaran turbin dan generator sehingga mencapai $1500 \mathrm{rpm}$ dengan toleransi $5 \%$. Dengan demikian dapat disimpulkan bahwa governor elektrik berbasis Arduino dapat diterapkan pada pengaturan putaran turbin screw.
\end{abstract}

Kata kunci: turbin screw, sistem kontrol,governor elektrik, arduino

\begin{abstract}
A microhydro based on screw turbine type has been realized in Ciherang village, Banjaran, West Java. But operation of the turbine and generator are unstable, due to load fluctuation. The system need a control system that can keep the turbine rotation in the range of $30 \mathrm{rpm}$ and the rotation of the generator in the range of $1500 \mathrm{rpm}$. In this paper study of the development of screw turbinecontrol system based on electric governor is presented. This electric governor is based on Arduino namely Arduino Mega 2560 dan Arduino Uno and equipped with a generator speed sensor send and electric motor as an actuator to adjust the opening of the bucket. The system test results show that the controller based on Arduino can adjust the turbine and generator rotation so that it reaches $1500 \mathrm{rpm}$ with a tolerance of $5 \%$. Thus it can be concluded that Arduino-based electrical governors can be applied to control screw turbine speed.
\end{abstract}

Keywords: screw turbine, control system, digital governor, arduino 
Kristyadi, dkk

\section{PENDAHULUAN}

Suatu pembangkit listrik memerlukan putaran yang konstant supaya menghasilkan listrik dengan frekuensi yang constant (Fengpan \& Wenhua, 2013). Turbin screw merupakan salah satu jenis turbin air untuk pembangkit listrik tenaga air dengan head yang rendah serta putaran rendah(Erinofiandi, Syaiful, \& Prayitno, 2015)(Date \& Akbarzadeh, 2009)(Laghari, Mokhlis, Bakar, \& Hasmaini, 2013). Sistem pengaturan putaran turbin screw dapat dilakukan dengan sistem mekanik maupun elektrik. Pengaturan putaran turbin screw pada putaran rendah menggunakan governormekanik mempunyai beberapa kelemahan antara lain kurang presisi dan kurang stabil (Water \& Aggidis, 2015)(Rohmer, Knittel, Strurtzer, Flienler, \& Renaud, 2016). Penelitian ini didasari atas kasus dimana pengaturan turbin screw menggunakan governor mekanik kurang efektif. Diperlukan suatu system kontrol putaran berbasis governor elektrik untuk mengatur putaran turbin supaya lebih presisi. Governor elektrik berbasis microcontroller diperlukan untuk menjaga supaya putaran turbin dan generator berada pada daerah kerjanya dengan simpangan yang sangat kecil. Salah satu microcontroller yang saat ini popular adalah Arduino. Microcontroller berbasis Arduino saat ini sudah banyak diterapkan untuk pengaturan peralatan mekanik. Beberapa jenis Arduino yang banyak digunakan adalah Arduino Mega 2560 dan Arduino Uno. Arduino digunakan dalam penelitian ini karena faktor kemudahan pemrograman, kemudahan penyambungan antar muka dengan computer, harga murah dan ketersediaan di pasaran cukup banyak.

Sistem kontrol putaran turbin screw terdiri dari sensor, kontroler, actuator (Rorres, 2000)(Muller \& Senior, 2009)(Dellinger, Terfous, Garambois, \& Ghenaim, 2016). Sensor mendeteksi kecepatan putaran turbin, lalu sensor tersebut mengirimkan sinyal untuk diolah oleh kontroller yang telah diprogram, selanjutnya kontroller memberikan perintah untuk motor listrik yang bertindak sebagai aktuator untuk menggerakkan sebuah pintu air yang mengatur bukaan sehingga laju massa air yang masuk turbin dapat terkontrol seiring dengan perubahan kecepatan putaran akibat berubahnya beban generator. Pada tahapan ini pengembangan sistem kontrol berupa model namun dengan tingkat keakuratan yang tinggi sehingga model tersebut segera dapat diaplikasikan pada turbin yang sebenarnya. Sistem kontrol berbasis Arduino Mega 2560 dan Arduino Uno digunakan sebagai pengatur utama untuk menerima sinyal dari sensor dan memberikan sinyal perintah kepada aktuator.

Pada paper ini dipaparkan mengenai perencanaan, realisasi dan pengujian sistem kontrol elektrik putaran turbin berbasis Arduino yang nantinya bisa diaplikasikan pada pembangkit listrik skala kecil berbasis turbin screw. Tujuan dari penelitian adalah membangun sistem kontrol putaran turbin screw berbasis microcontroller Arduino khususnya Arduino Mega 2560 dan Arduino Uno sehingga turbin dan generator sehingga bisa menghasilkan putaran generator $1500 \mathrm{rpm}$.

\section{METODOLOGI}

Proses dari sistem kontrol governor elektrik adalah pengaturan kecepatan/putaran turbin. Dalam melakukan penelitian ini langkah atau tahapan yang dilakukan adalah mulai dari perencanaan, pembuatan alat dan pengujian. Perencanaan sistem kontrol mengikuti sistem kontrol tertutup (Muller \& Senior, 2009). Gambaran komponen pada sistem kontrol (loop) tertutup yang dimaksud digambarkan sebagai Process Flow Diagram (PFD) yang ditunjukkan pada Gambar 1. Pada gambar tersebut komponen-komponen yang diterapkan adalah pintu air sebagai obyek yang dikontrol, penggerak pintu sebagai aktuator, kontroler menggunakan Arduino, dan sensor dipasang pada poros turbin dan generator. 


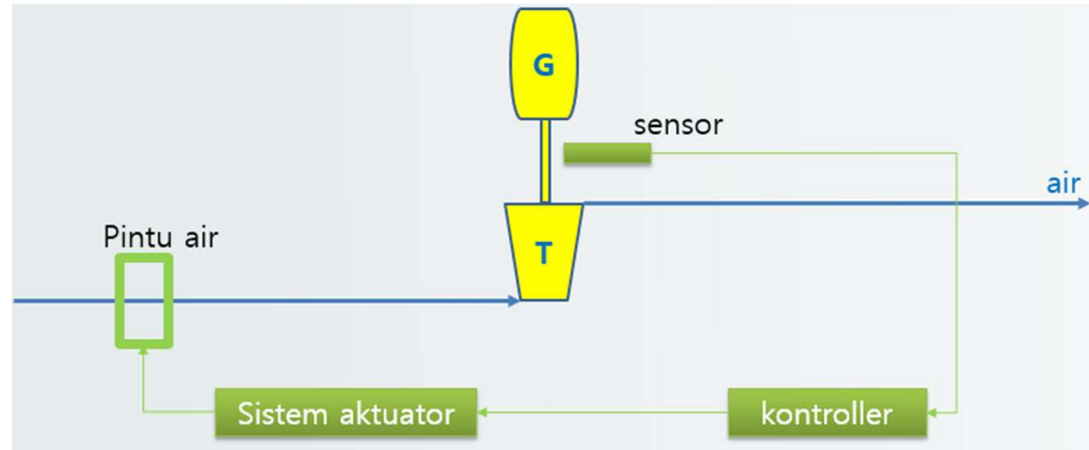

Gambar 1. Diagram PFD Sistem Governor Elektrik Secara Umum

Aliran air melewati dan memutar turbin, tinggi rendahnya putaran turbin dipengaruhi oleh debit air. Turbin dan generator digambarkan satu poros, sehingga ketika turbin berputar, maka generator ikut berputar (walaupun dalam kenyataanya terdapat gearbox dari turbin ke generator). Kecepatan putaran poros turbin diukur dengan sensor kecepatan putaran. Sensor tersebut mengirimkan data variabel kecepatan putar tersebut kepada kontroller. Kontroller mengolah informasi yang diberikan dan memutuskan perintah apa yang akan dikerjakan oleh sistem actuator (Sushant, Kulkarni, \& Dhande, 2012). Sistem aktuator menerima perintah kontroller dan melakukan gerak / aksi untuk memperlebar atau memperkecil bukaan pada pintu air. Lebar bukaan pada pintu air tersebutakan mempengaruhi debit air yang menyebabkan perubahan kecepatan turbin.

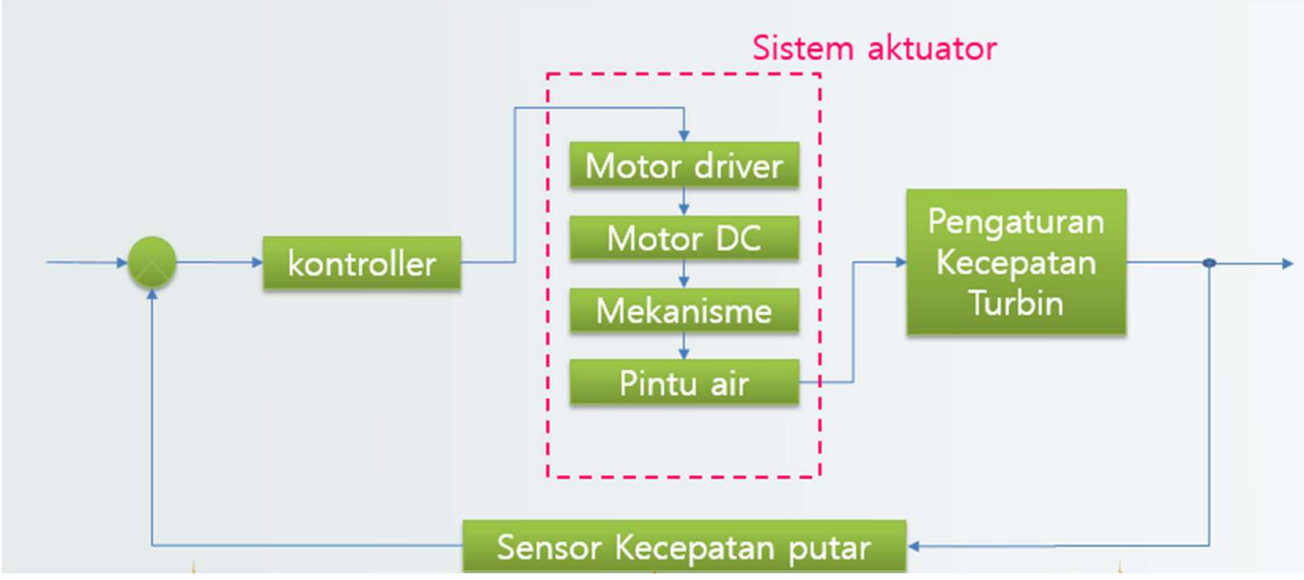

Gambar 2. Skema Sistem Kontrol Loop Tertutup Governor Elektrik

Skema sistem kontrol loop tertutup dapat dilihat pada Gambar 2. dan gambar komponen ditunjukkan pada Gambar 3. Output dari proses tersebut adalah putaran turbin yang diukur dengan sensor kecepatan putar yang terpasang. Informasi yang telah dibaca sensor lalu diserahkan untuk dibandingkan dengan set point. Selanjutnya informasi tersebut dikirim ke kontroller, kontroller mengolah informasi dan memutuskan perintah apa yang akan dikerjakan oleh aktuator yang terdiri dari motor driver, motor DC, mekanik dan pintu. Motor Driver berfungsi untuk meregulasi daya masukan ke motor listrik dan arah arusnya, sehingga motor listrik dapat bekerja dengan kecepatan putar tertentu, arah tertentu, dan berhenti bergerak pada titik tertentu. Mekanisme merupakan penghubung dari putaran motor listrik menjadi gerak translasi naik turun dari pintu air. Pintu air merupakan komponen aktuator terakhir yang bersinggungan langsung untuk mengatur jumlah fluida atau air yang diizinkan melalui turbin. 


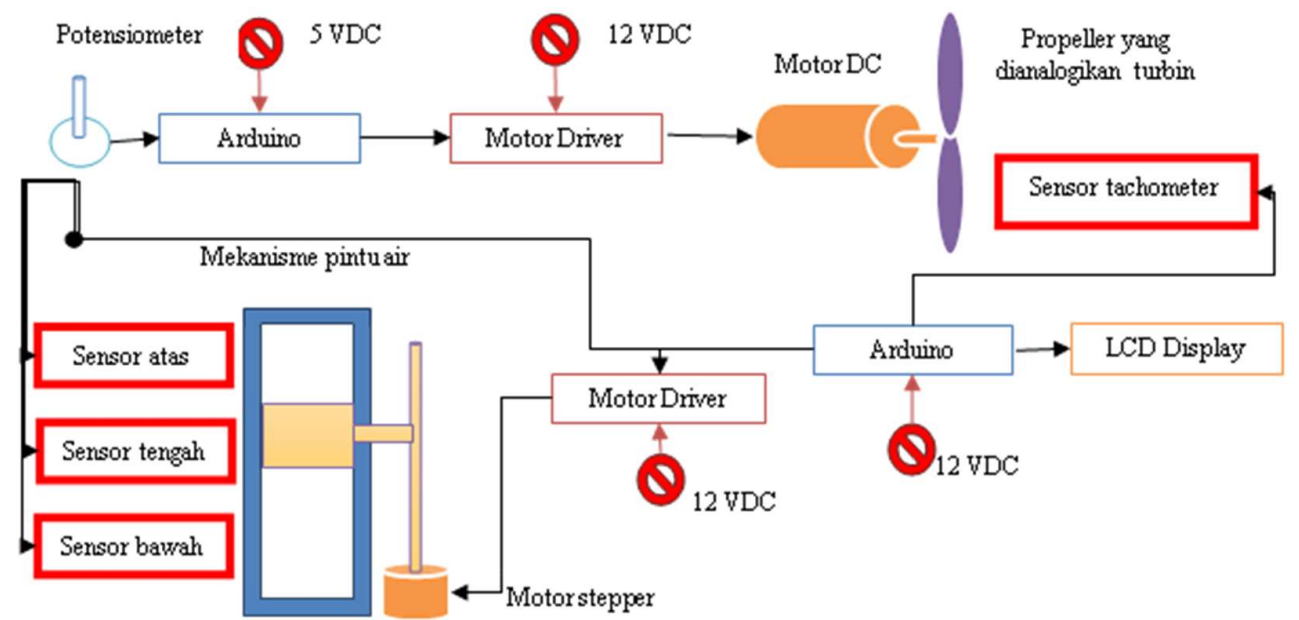

Gambar 3. Komponen Sistem Governor Elektrik

Komponen utama pada rancang bangun governor elektrik adalah Arduino Mega 2560, digunakan sebagai kontroller governor elektrik(motor stepper) dan Arduino Uno R3 sebagai kontroller pengontrolan motor DC. Wiring dari maisng-masing sistem adalah seperti ditunjukkan pada Gambar 4 dan Gambar 5.

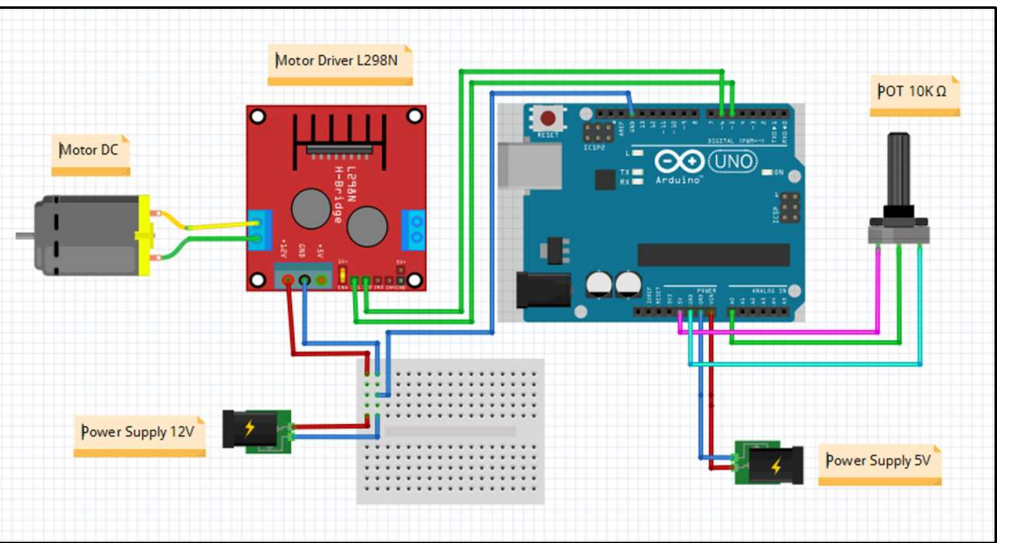

Gambar 4. Wiring Kontrol Motor DC dengan PWM berbasis Arduino Uno

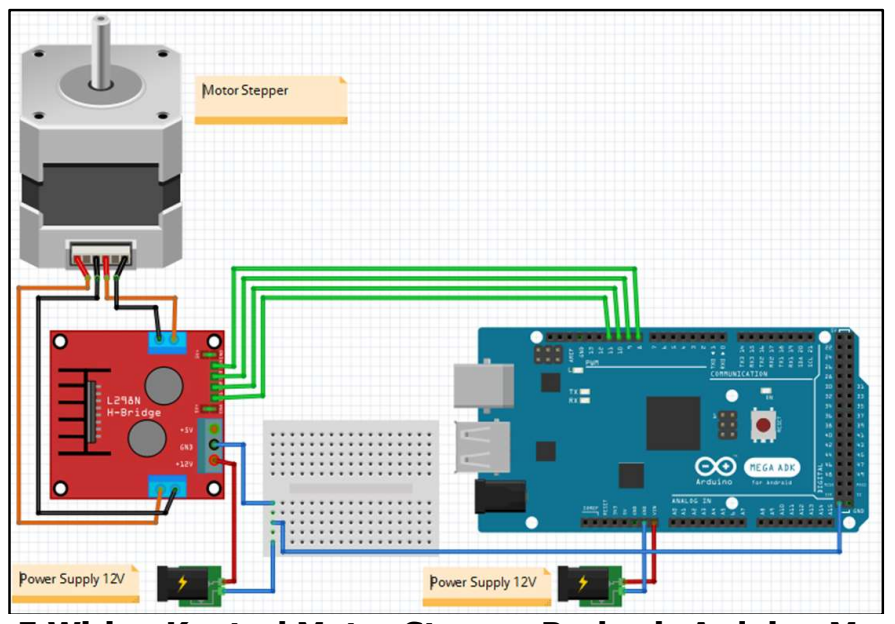

Gambar 5 Wiring Kontrol Motor Stepper Berbasis Arduino Mega 2560 
Metode pengontrolan motor yang digunakan adalah PWM, melalui inputan dari potensiometer $10 \mathrm{k} \Omega$. Potensiometer dihubungkan dengan sumber daya $5 \mathrm{~V}$, dan kaki tengahnya dihubungkan pada pin analog Arduino. Sedangkan Motor DC dihubungkan dengan motor driver dan motor driver terhubung dengan pin PWM Arduino. Nilai analog pembacaan potensiometer yang dibaca oleh Aduino dengan nilai 0-1023 dikonversi menjadi nilai 0-255. Nilai 0-255 tersebut selanjutnya diberikan kepada motor driver, untuk memberikan perintah gerakan kepada motor aktuator.

Sensor IR menangkap sinyal dari bilah turbin yang berjumlah empat, sehingga satu kali sinyal terbaca setara dengan seperempat putaran telah tercapai, atau satu putaran setara dengan sensor membaca objek sebanyak empat kali. Selanjutnya perhitungan rpm didefinisikan sebagai berikut:

$$
n(\text { rpm })=\frac{60000}{\text { Interval Tachomete }(m s)} \times \frac{\text { jumlah pembacaan sensor }}{\text { jumla bilah objek ukur }}
$$

Dari Persamaan (1) konstanta 60000 didapat dari konversi dari 1 menit ke milisekon. Selanjutnya karena menggunakan metode interval konstan maka kecermatan tachometer sangat bergantung dari nilai interval tersebut dan jumlah bilah objek ukur. Misal jika suatu poros dengan jumlah bilah objek ukur satu, interval tachometer 1 sekon atau $1000 \mathrm{~ms}$ dan berputar dengan kecepatan $30 \mathrm{rpm} .30 \mathrm{rpm}$ setara dengan 1 putaran terjadi dalam waktu 2 sekon. Tetapi karena interval tachometernya adalah 1 sekon dan jumlah bilah satu, maka yang terjadi adalahpembacaan pada tachometerdidetik pertama adalah $60 \mathrm{rpm}$ dan didetik kedua terbaca $0 \mathrm{rpm}$, detik ketiga $60 \mathrm{rpm}$, detik keempat $0 \mathrm{rpm}$ begitu seterusnya. Jadi kecermatan tachometer atau kemampuan tachometer menunjukkan skala terkecil dengan metode interval konstan sangat bergantung dari nilai interval dan jumlah bilah objek ukur. Rumus kecermatan tachometer atau skala terkecil yang dapat ditunjukkan tachometer didefinisikan sebagai berikut:

$$
\text { kecermatan }(r p m)=\frac{60000}{\text { Interval Tachometer }(m s) \times \text { jumlah bil objek ukur }}
$$

Terdapat sensor pendeteksi posisi pintu air yang berfungsi untuk mengetahui dimana posisi pintu air berada yang mengindikasikan atau mewakili debit air yang masuk ke turbin. Fungsi dari sistem juga sebagai pemberhenti gerakan motor aktuator. Sistem inilah yang dapat mengatur pintu air berada pada posisi bukaan tertentu sehingga dapat mengatur laju massa air yang mengalir ke turbin secara akurat. Prinsip kerja dari sistem ini adalah memasang beberapa sensor infra red, pada jarak ketinggian tertentu yang teratur. Pada model yang dibuat sensor yang digunakan berjumlah tiga, yang disebut sensor atas, tengah, dan bawah. Jadi jika misalkan pintu air saat ini berada di atas, maka sensor atas akan menyala, dan informasi tersebut dibaca oleh arduino. Jika pada kondisi tersebut sistem memerintahkan untuk menutup pintu hingga posisi tengah. Aktuator akan bergerak menutup pintu air, hingga sensor tengah menyala. Ketika sensor tengah menyala dan terbaca oleh kontroller, maka kontroller langsung memerintahkan motor untuk berhenti. Rangkaian simulasi alat peraga governor elektrik merupakan penggabungan dari sistem tachometer, sistem pengendalian motor stepper, dan sistem pendeteksi posisi pintu air. Tachometer berfungsi untuk mengukur kecepatan turbin dalam satuan rpm. Nilai rpm yang telah terukur akan dibandingkan dengan nilai set point, yang menentukan perintah apa yang akan diberikan kepada motor stepper. Apakah motor stepper akan tetap diam, bergerak searah putaran jarum jam (CW) yang menggerakkan pintu air keatas, atau bergerak berlawanan arah putaran jarum jam (CCW) yang menggerakkan pintu air kebawah. Jika perintah yang dijalankan adalah motor bergerak 
Kristyadi, dkk

maka sensor pendeteksi posisi pintu air akan mendeteksi dimana seharusnya pintu air berhenti, dan jika sensor yang dimaksud telah menerima sinyal maka kontroller akan menghentikan gerakan motor.

Program yang digunakan pada rangkaian governor elektrik adalah penggabungan dari program-program sebelumnya, yang telah dimodifikasi. Perubahan paling signifikan adalah di bagian aktuator, yaitu syarat kondisi motor stepper untuk bergerak dan berhenti. Secara mudah bagian input dan output dari simulasi alat peraga governor elektrik ini adalah sebagai berikut Jika rpm < 200, maka pintu berada di atas, Jika $200 \geq$ rpm $\leq 300$, maka pintu berada di tengah, dan Jika rpm > 300, maka pintu berada di bawah. Dari kondisi tersebut jika misalkan rpm terukur adalah $200 \mathrm{rpm}$ dan posisi pintu berada di bawah atau di tengah. Maka kontroller akan memerintahkan motor driver untuk menggerakkan motor stepper dalam arah CW dan menggerakkan pintu air keatas. Motor dan pintu akan terus bergerak keatas hingga sensor posisi pintu air atas terbaca. Ketika sensor pintu air atas terbaca maka kontroller akan memerintahkan motor driver untuk menghentikan gerakan motor stepper. Dari syarat kondisi tersebut jika nilai rpm dan posisi pintu air sudah sesuai dengan pernyataan. Maka tidak akan ada pergerakan motor yang terjadi. Kondisi ini terjadi misalkan ketika posisi pintu berada di atas dan nilai rpm berubah dari $150 \mathrm{rpm}$ menjadi $100 \mathrm{rpm}$. Karena pernyataan tersebut masih sesuai dengan pernyataan pertama yaitu nilai rpm $<200$ dan posisi pintu berada di atas maka tidak akan ada pergerakan motor yang terjadi. Ketika terjadi pergerakan motor stepper atau pintu air, sistem tachometer tidak akan memulai pengukuran. Hal ini dilakukan untuk menghindari sistem mendapatkan nilai rpm yang baru sebelum sistem aktuator berhenti bekerja, cara ini berfungsi untuk menghindari errorpada program. Untuk melakukan dua sistem yang bekerja sekuensial tersebut dilakukan dengan memasukkan kedua program pada bagian "void loop" secara berurutan. Pada bagian persiapan sistem atau "void setup". Sistem diatur untuk menggerakkan motor stepper sehingga pintu air bergerak ke posisi atas. Setelah posisi pintu mencapai atas atau dari awal posisi pintu sudah berada di atas, program berulang atau "void loop" mulai berjalan.

Tahapan selanjutnya adalah realisasi. Hasil perencanaan direalisasikan dalam sistem kontrol putaran. Sistem governor dimulai dari sensor tachometer yang terus menerus pada selang waktu tertentu mengukur kecepatan turbin. Kontroller menerima informasi tersebut dan menampilkannya pada LCD display, dan juga membandingkan data tersebut terhadap setpoint. Bedasarkan informasi yang telah diolah tersebut, kontroller akan memerintahkan motor driver untuk tetap diam atau bergerak keposisi yang dituju. Sistem aktuator yang digunakan pada model governor elektrik adalah motor driver yang terhubung dengan motor stepper, dan motor stepper terhubung dengan mekanisme poros ulir pintu air. Pada pintu air juga dilengkapi dengan ketiga sensor pendeteksi posisi yang dinamakan sensor atas, sensor tengah, dan sensor bawah. Sensor pendeteksi posisi tersebut mempunyai dua fungsi yaitu untuk mengetahui dimana posisi pintu air saat ini, dan sebagai penanda untuk menghentikan motor aktuator ketika bergerak, sehingga posisi pintu air tepat seperti yang diinginkan. Tahapan selanjutnya adalah pengujian. Hasil pembuatan system contro/kemudian diuji pada turbin screw yang telah terpasang pada pembangkit listrik microhydro.

\section{HASIL DAN PEMBAHASAN}

\subsection{Pengujian Kecepatan Putaran Motor DC metode PWM}

Pengujian kecepatan putaran motor DC dengan metode PWM dilakukan untuk mendapatkan nilai hubungan antara nilai pwm dengan kecepatan putaran motor (rpm). Hasil pengujian digunakan untuk menentukan setting batas bawah dan batas atas kecepatan putaran motor, sehingga diperoleh variasi kecepatan putaran yang baik untuk diaplikasikan pada model 
simulasi governor elektrik (Hannet, Fardanesh, \& Fektes, 1994)(Lubitz, Lyons, \& Simsons, 2014).

Selanjutnya dari data yang telah didapatkan akan digunakan untuk mensetting batas atas dan batas bawah kecepatan putaran motor DC. Dari desain awal perancangan model simulasi governor, putaran stabil atau posisi pintu air berada di tengah jika $200<\mathrm{rpm}<300$. Dari jangkauan nilai tersebut maka ditentukan nilai batas bawah putaran ada disekitar $100 \mathrm{rpm}$, dan nilai batas atas ada di sekitar $400 \mathrm{rpm}$. Untuk mendapatkan nilai sekitar $100 \mathrm{rpm}$ maka digunakan nilai PWM 25 yang menghasilkan 120 rpm, dan untuk mendapatkan nilai sekitar 400 rpm maka digunakan nilai PWM 40 yang menghasilkan 472 rpm. Dengan memasukkan nilai tersebut ke dalam program, maka saat potensiometer berada di ujung kiri kecepatan motor adalah $120 \mathrm{rpm}$, dan saat potensiometer berada di ujung kanan kecepatan motor adalah 472 rpm. Hasil dari pengujian kecepatan putaran motor DC dari beberapa nilai PWM ditampilkan pada Tabel 1.

Tabel 1. Hasil Pengujian PWM Motor DC

\begin{tabular}{|c|c|c|}
\hline Nilai PWM & Duty Cycle (\%) & Kecepatan putar motor (rpm) \\
\hline $\mathbf{0}$ & 0 & 0 \\
\hline $\mathbf{2 5}$ & 9,8 & 120 \\
\hline $\mathbf{3 0}$ & 11,7 & 247 \\
\hline $\mathbf{4 0}$ & 15,7 & 472 \\
\hline $\mathbf{6 0}$ & 23,5 & 787 \\
\hline $\mathbf{8 0}$ & 31,4 & 1080 \\
\hline $\mathbf{1 0 0}$ & 39,2 & 1342 \\
\hline $\mathbf{1 2 0}$ & 47,1 & 1590 \\
\hline $\mathbf{1 4 0}$ & 54,9 & 1830 \\
\hline $\mathbf{1 6 0}$ & 62,7 & 2047 \\
\hline $\mathbf{1 8 0}$ & 70,56 & 2265 \\
\hline $\mathbf{2 0 0}$ & 78,4 & 2490 \\
\hline $\mathbf{2 2 0}$ & 86,3 & 2722 \\
\hline $\mathbf{2 4 0}$ & 94,1 & 2947 \\
\hline $\mathbf{2 5 5}$ & 100 & 3112 \\
\hline
\end{tabular}

\subsection{Pengujian Governor Elektrik}

Pengujian governor elektrik dilakukan untuk mengetahui apakah sistem dapat bekerja sesuai dengan perintah yang diberikan yaitu sesuai dengan syarat kondisi sebagai berikut:

> Saat pertama kali dinyalakan, pintu bergerak ke atas (hanya dilakukan satu kali saat program baru dinyalakan)

$>$ Jika rpm $<200$, pintu berada di atas

$>$ Jika $200 \leq$ rpm $\leq 300$, pintu berada di tengah

$>$ Jika rpm>300, pintu berada di bawah

Pengujian pertama adalah saat program dinyalakan. Pada bagian awal ini perintah yang diberikan adalah pintu bergerak ke posisi atas, jika pintu telah berada di posisi atas maka langsung dilanjutkan ke bagian program selanjutnya. Hasil pengujian bagian setup ini ditampilkan pada Gambar 6 berikut. 


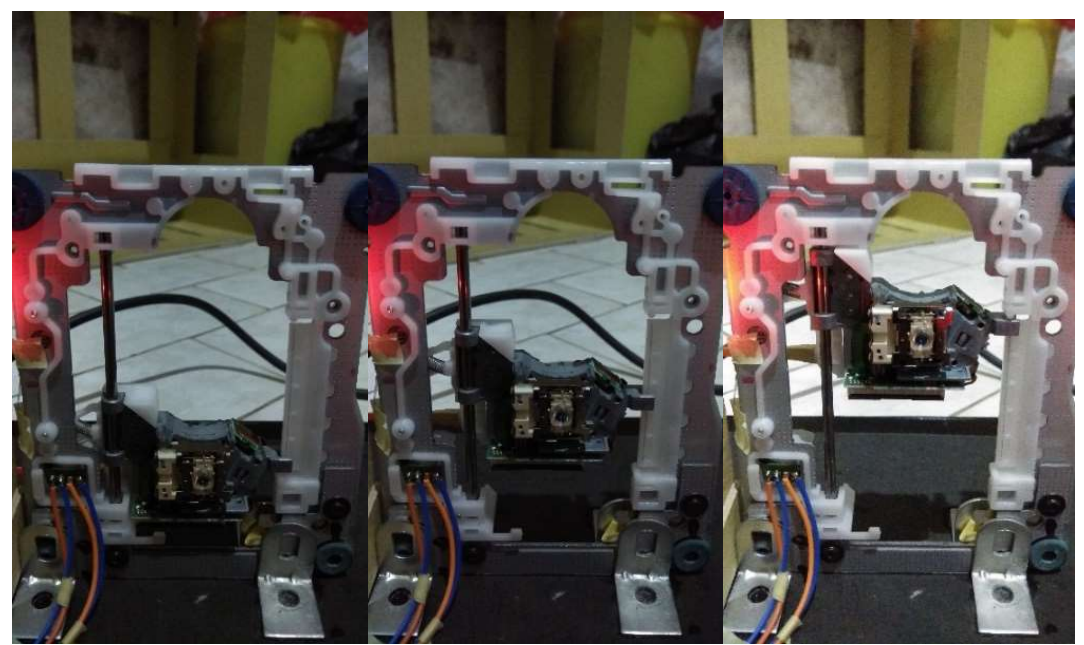

Gambar 6. Pintu Air Bergerak Ke Posisi Atas Pada Awal Program

Selanjutnya melakukan pengujian kedua yaitu pada bagian program utama atau program berulang. Pada bagian ini parameter pengujian berhasil jika alat mampu untuk mengolah input rpm dari pembacaan tachometer, dan memerintahkan motor untuk menggerakkan pintu air sesuai dengan syarat kondisi yang telah dituliskan dibagian sebelumnya. Hasil dari pengujian ditampilkan pada Tabel 2.

Tabel 2. Hasil Pengujian Model Simulasi Governor Elektrik

\begin{tabular}{|c|c|c|}
\hline rpm & Posisi pintu & Gambar posisi pintu \\
\hline 120 & Atas & \\
\hline 127 & Atas & \\
\hline 157 & Atas & \\
\hline 180 & Atas & \\
\hline 217 & Tengah & \\
\hline 240 & Tengah & \\
\hline 270 & Tengah & \\
\hline 285 & Tengah & \\
\hline 307 & Bawah & \\
\hline 330 & Bawah & \\
\hline 375 & Bawah & \\
\hline 472 & Bawah & \\
\hline
\end{tabular}


Dari hasil pengujian yang telah dilakukan, model simulasi governor elektrik dapat mengolah input rpm dari tachometer dan memerintahkan motor untuk menggerakkan pintu air ke posisi yang tepat. Sehingga dapat disimpulkan jika model simulasi ini berhasil bekerja dengan baik.

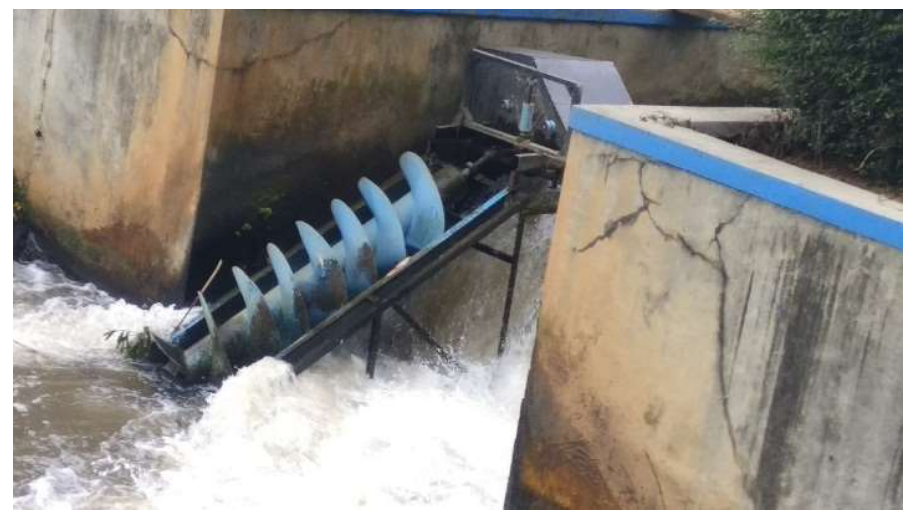

Gambar 7. Instalasi Mikrohidro Berbasis Turbin Screw

Governor elektrik yang sudah dikembangkan diaplikasikan dan digunakan untuk mengatur putaran turbin screw pada pembangkit listrik microhydro yang terpasang pada saluran irigasi di Desa Ciherang Kabupaten Bandung. Pada kondisi eksisting pembangkit tersebut sudah beroperasi namun dengan kondisi frekuensi listrik yang tidak beraturan karena putaran turbin berubah-ubah tergantung dari debit air yang mengalir. Instalasi microhydro terlihat pada Gambar 7.

Pada rangkaian governor elektrik turbin air screw pengukuran kecepatan putaran dilakukan pada poros generator. Hal ini berarti yang bertindak sebagai input dari sistem kontrol adalah kecepatan putaran generator dalam satuan rpm dan yang bertindak sebagai output adalah posisi pintu air yang didefinisikan lebar bukaan pintu dari dasar irigasi.

Jangkauan pintu air berpindah adalah $150 \mathrm{~mm}$, yang ditempuh dari lebar tertutup maksimal pada $200 \mathrm{~mm}$ dari dasar irigasi sampai lebar terbuka maksimal pada $350 \mathrm{~mm}$ dari dasar irigasi. Perhitungan dari variasi putaran generator dengan posisi pintu air telah dilakukan pada penelitian sistem kontrol tipe mekanik sebelumnya. Dengan menggunakan tujuh sensor posisi dengan jarak interval $25 \mathrm{~mm}$, didapatkan hubungan antara variasi putaran generator dengan lebar bukaan pintu air yang ditampilkan pada Tabel 3.

Tabel 3. Hubungan Antara Putaran Generator dengan Lebar Bukaan Pintu Air

\begin{tabular}{|c|c|}
\hline $\begin{array}{c}\text { Lebar bukaan pintu } \\
\text { dari dasar } \mathbf{( m m )}\end{array}$ & Putaran Generator (rpm) \\
\hline 350 & 1083 \\
\hline 325 & 1222 \\
\hline 300 & 1361 \\
\hline 275 & 1500 \\
\hline 250 & 1660 \\
\hline 225 & 1821 \\
\hline 200 & 1981 \\
\hline
\end{tabular}

Selanjutnya adalah mencari interval rpm pada setiap posisi bukaan pintu. Metode yang digunakan adalah dengan nilai rata-rata. Batas bawah rpm dari posisi sensor adalah nilai ratarata dari nilai rpm pada posisi tersebut dengan nilai rpm pada posisi sebelumnya, dan batas 
atas rpm dari posisi sensor adalah nilai rata-rata dari nilai rpm pada posisi tersebut dengan nilai rpm pada posisi setelahnya. Hasil dari nilai batas atas dan batas bawah dibulatkan tanpa nilai desimal, hal ini dikarenakan kecermatan tachometer yang digunakan pada rangkaian adalah $1 \mathrm{rpm}$. Batas-batas operasi sensor ditunjukkan pada Tabel 4.

Tabel 4. Batas Bawah dan Atas Rpm dari Setiap Posisi Sensor

\begin{tabular}{|c|c|c|c|}
\hline $\begin{array}{c}\text { Sensor } \\
\text { posisi }\end{array}$ & $\begin{array}{c}\text { Lebar bukaan pintu } \\
\text { dari dasar(mm) }\end{array}$ & $\begin{array}{c}\text { batas } \\
\text { bawah rpm }\end{array}$ & $\begin{array}{c}\text { batas atas } \\
\text { rpm }\end{array}$ \\
\hline A & 350 & - & 1153 \\
\hline B & 325 & 1153 & 1292 \\
\hline C & 300 & 1292 & 1431 \\
\hline D & 275 & 1431 & 1580 \\
\hline E & 250 & 1580 & 1741 \\
\hline F & 225 & 1741 & 1901 \\
\hline G & 200 & 1901 & - \\
\hline
\end{tabular}

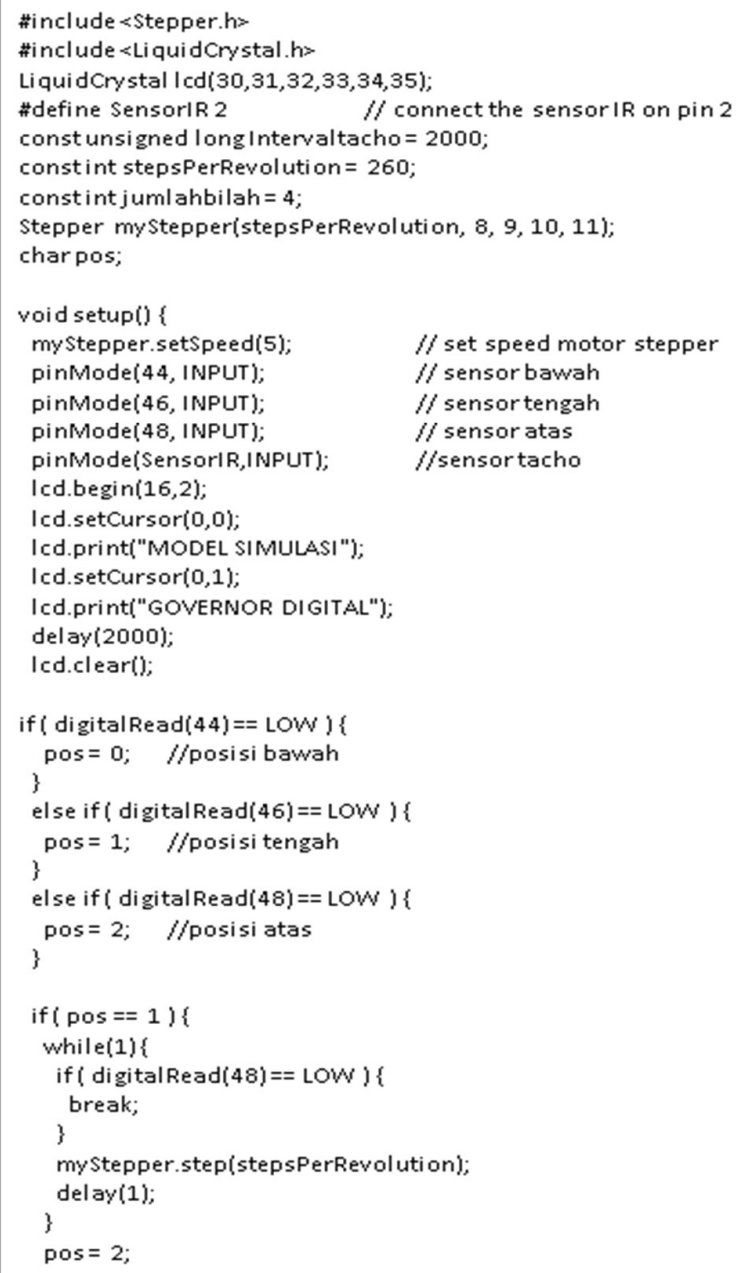

Gambar 8. Listing Program Kontroller 
Berdasarkan Tabel 4 tersebut kemudian dilakukan pembuatan program pada kontroler yang mengatur posisi sensor dan posisi pembukaan pintu. Sensor posisi pintu menggunakan tujuh sensor. Formula dari pemrograman governor elektrik ditentukan sebagai berikut.

$>$ Jika rpm < 1153, maka pintu air berada pada posisi A

$>$ Jika $1153 \leq \mathrm{rpm}<1292$, maka pintu air berada pada posisi B

$>$ Jika $1292 \leq \mathrm{rpm}<1431$, maka pintu air berada pada posisi C

$>$ Jika $1431 \leq \mathrm{rpm} \leq 1580$, maka pintu air berada pada posisi $\mathrm{D}$

$>$ Jika $1580<\mathrm{rpm} \leq 1741$, maka pintu air berada pada posisi $\mathrm{E}$

$>$ Jika $1741<\mathrm{rpm} \leq 1901$, maka pintu air berada pada posisi $\mathrm{F}$

$>$ Jika rpm > 1901, maka pintu air berada pada posisi G

Listing program pengontrolan ditunjukkan pada Gambar 8.

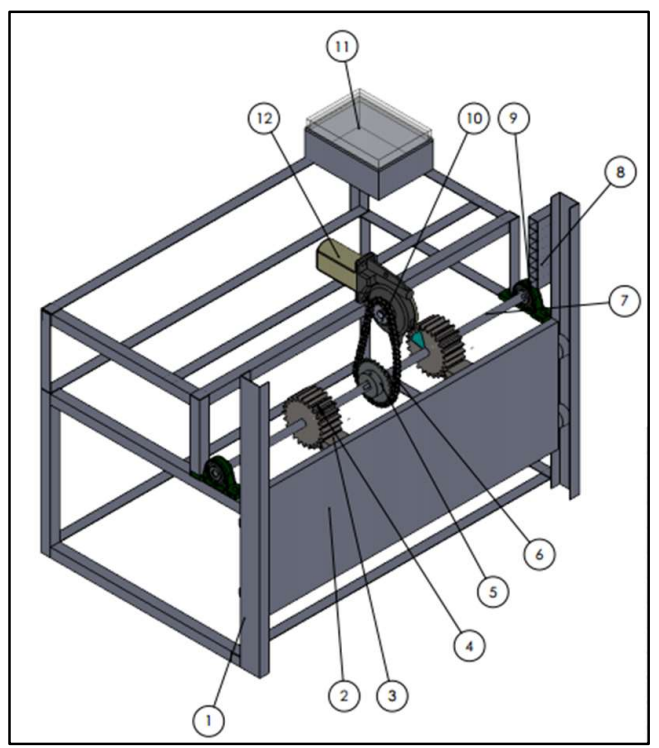

Gambar 9. Sistem Transmisi Pintu Air

Tabel 5. Sistem Transmisi Pintu Air

\begin{tabular}{|l|l|}
\hline Spesifikasi motor & 24V 360W \\
\hline Putaran motor & $30 \mathrm{rpm}$ \\
\hline Sprocket 1 & Diameter pitch $50 \mathrm{~mm}$ \\
\hline Sprocket 2 & Diameter pitch $100 \mathrm{~mm}$ \\
\hline Poros & Diameter $19 \mathrm{~mm}$, panjang $100 \mathrm{~mm}$ \\
\hline Roda gigi pinion & Diameter pitch $1000 \mathrm{~mm}$ \\
\hline Putaran poros dan pinion & $15 \mathrm{rpm}$ \\
\hline Bobot pintu air & $67 \mathrm{~kg}$ \\
\hline
\end{tabular}

Secara umum perangkat keras yang digunakan sebagai pengujian yang terdiri dari turbin, generator, pintu air poros dan komponen-komponen lain dijelaskan melalui gambar teknik dari hasil perancagan sistem transmisi pintu air yang ditunjukkan pada Gambar 9 dan untuk spesifikasi dari sistem transmisi berikut ditunjukkan pada Tabel 5. 


\section{KESIMPULAN}

Sistem control putaran turbin screw dapat dilakukan dengan elektronik berbasis Mikrokontroller Arduino Mega 2560 dan Arduino Uno dengan cara mengatur pembukaan pintu air. Sistem control menggunakan loop tertutup yang mengatur putaran poros turbin berdasarkan sensor putaran turbin sebagai umpan balik bagi kontroler. Sebagai aktuator adalah motor penggerak pintu. Hasil pengujian system menunjukkan bahwa sistem dengan Arduino ini dapat mengatur putaran turbin dan generator sehingga mencapai 1500 rpm dengan toleransi $5 \%$. Dengan demikian dapat disimpulkan bahwa governor elektrik berbasis Arduino dapat diterapkan pada pengaturan putaran turbin screw.

\section{DAFTAR RUJUKAN}

Date, A., \& Akbarzadeh, A. (2009). Design and Cost Analysis of Low Head Simple Reaction hydro Turbine for Remote area Power Supply. Journal of Renewable Energy, 34, 4094015.

Dellinger, G., Terfous, A., Garambois, P., \& Ghenaim, A. (2016). Experimental Investigation and Performance Analysis of Archimedes Screw Generator. Journal of Hydraulic Research, 1-13.

Erinofiandi, M., Syaiful, A., \& Prayitno. (2015). Electric Power generation From Low Haed Simple Turbine for Remote Area Power Supply. Journal Technologies, 74(5), 21-25.

Fengpan, L., \& Wenhua, L. (2013). Turbine Governor System Frequency Measurement Based on DSP. 2 nd International Conference on Inteligent System and Applied Material.

Hannet, L. N., Fardanesh, B., \& Fektes, J. W. (1994, November). Field Tests to Validate Hydro Turbine-Governor Model Structuire and Parameters. IEEE Transaction on Power System, 9(4), 1744-1751.

Laghari, J. A., Mokhlis, H., Bakar, A. H., \& Hasmaini, M. (2013). A Comprehensive Overview of New Design in Hyadraulic Electrical Equipment and Controllers of Mini Hydro Power Plants Making it Cost Effective Technology. Journal of Renewable And Sustainable Energy Reviews, 20, 279-293.

Lubitz, W. D., Lyons, M., \& Simsons, S. (2014). Performance model of Archimedes screwhydro turbines with variable fill level. Journal of Hydraulic Engineering, 140(10), 1-11.

Muller, G., \& Senior, J. (2009). Simplified theory of Archimedean screws. Journal of Hydraulic Research, 4Л(5), 666-669.

Rohmer, J., Knittel, D., Strurtzer, G., Flienler, D., \& Renaud, J. (2016). Modeling and experimental results of an Archimedes screw turbine. Journal of Renewable Energy, 94, 136-146. 
Rorres, C. (2000). The turn of the screw. Optimal design of an Archimedes screw. Journal of Hydraulic Engineering, 126(1), 72-80.

Sushant, R., Kulkarni, S. A., \& Dhande, N. B. (2012, October). Design and Development of Microcontroller Based Electronic Speed Governor for Genset/Automative Engine, International Journal of Engineering and Science, 1(5), 26-33.

Water, S., \& Aggidis, G. A. (2015). Over 2000 Years in Review: Revival of The Archimedes Screw From Pup to Turbine. Journal of Renewable and Sustainable Energy Reviews, 51, 497-505. 